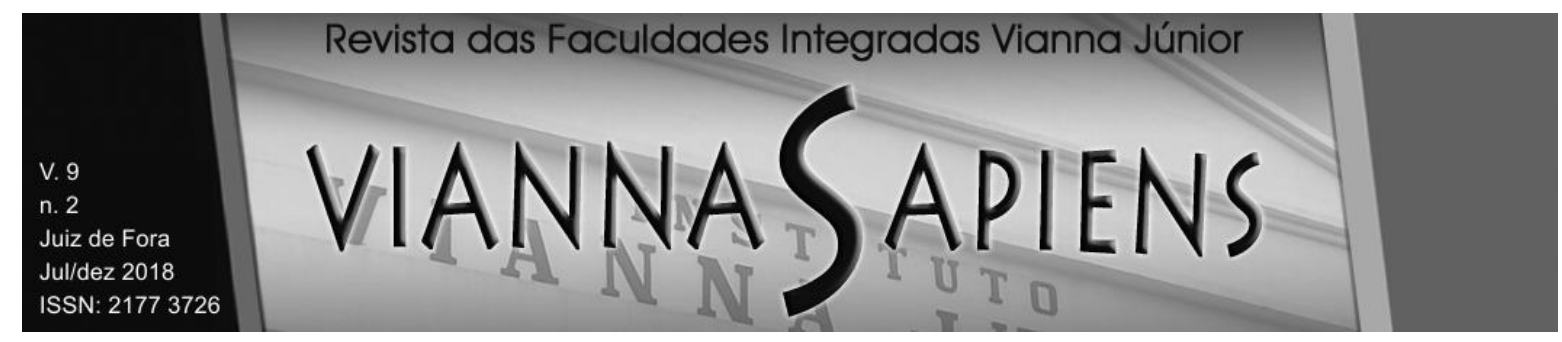

\title{
O PRINCÍPIO DA DIGNIDADE DA PESSOA HUMANA E A (IN) \\ CONSTITUCIONALIDADE DO REGIME DISCIPLINAR DIFERENCIADO FRENTE ÀS GARANTIAS CONSTITUCIONAIS \\ DOI: 10.31994/rvs.v9i2.395
}

Débora Guedes Schlaucher ${ }^{1}$
Diogo Luiz Manganelli de Oliveira ${ }^{2}$

\section{RESUMO}

O presente trabalho tem por objetivo analisar os contornos da constitucionalidade do regime disciplinar diferenciado frente aos direitos e garantias fundamentais do ser humano trazidos pelo artigo $5^{0}$ da Constituição Federal, bem como o princípio da dignidade da pessoa humana, elencado em seu artigo primeiro. A metodologia utilizada foi, principalmente, a documental, através de obras jurídicas, jurisprudências consolidadas dos nossos Tribunais Superiores, assim como dados estatísticos. Pode-se concluir do estudo em analise que a implementação do Regime Disciplinar Diferenciado, que surgiu para aliviar a insegurança pública e disciplinar de forma mais severa os detentos, viola, expressamente, o que nossa Carta Magna assegura no tocante à dignidade física, psíquica e moral dos indivíduos.

\footnotetext{
${ }^{1}$ Advogada e Pós Graduada em Direito Público pela Rede de Ensino LFG, https://orcid.org/00000001-7112-5466

${ }_{2}^{2}$ Advogado, Pós Graduado em Direito Empresarial pela PUC/MG e mestrando em Direito e Inovação pela UFJF, https://orcid.org/0000-0002-0495-0519
} 


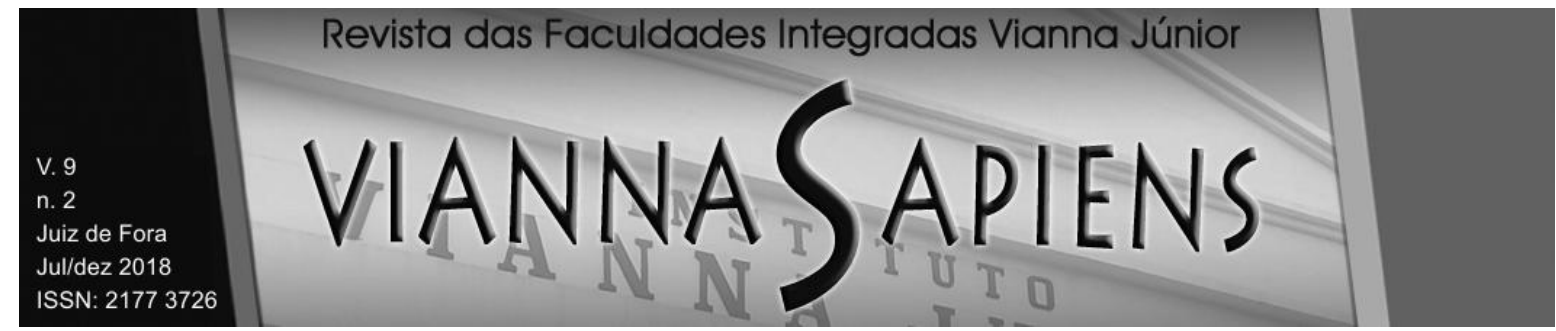

PALAVRAS-CHAVE: DIREITOS E GARANTIAS FUNDAMENTAIS. PRINCÍPIOS. CONSTITUCIONALIDADE. DIGNIDADE DA PESSOA HUMANA. REGIME DISCIPLINAR DIFERENCIADO.

THE PRINCIPLE OF THE DIGNITY OF THE HUMAN PERSON AND THE (IN) CONSTITUTIONALITY OF THE DISCIPLINARY REGIME DIFFERENTIATED FROM CONSTITUTIONAL GUARANTEES

\begin{abstract}
The present work aims to analyze the contours of the constitutionality of the disciplinary differentiated regime from the fundamental rights and guarantees of human beings brought by article 5 of our Federal Constitution, as well as the principle of the dignity of the human person listed in its first article. The methodology used was mainly documentary, through legal works, consolidated jurisprudence of our High Courts, as well as statistical data. It can be concluded from the study under analysis that the implementation of the Differentiated Disciplinary Regime, which emerged to alleviate public insecurity and discipline inmates more severely, violates, expressly, what our Constitution ensures with respect to the physical, psychic and morality of individuals.
\end{abstract}

KEYWORDS: FUNDAMENTAL RIGHTS AND GUARANTEES. PRINCIPLES. CONSTITUTIONALITY. DIGNITY OF HUMAN PERSON. DISCIPLINARY REGIME. 


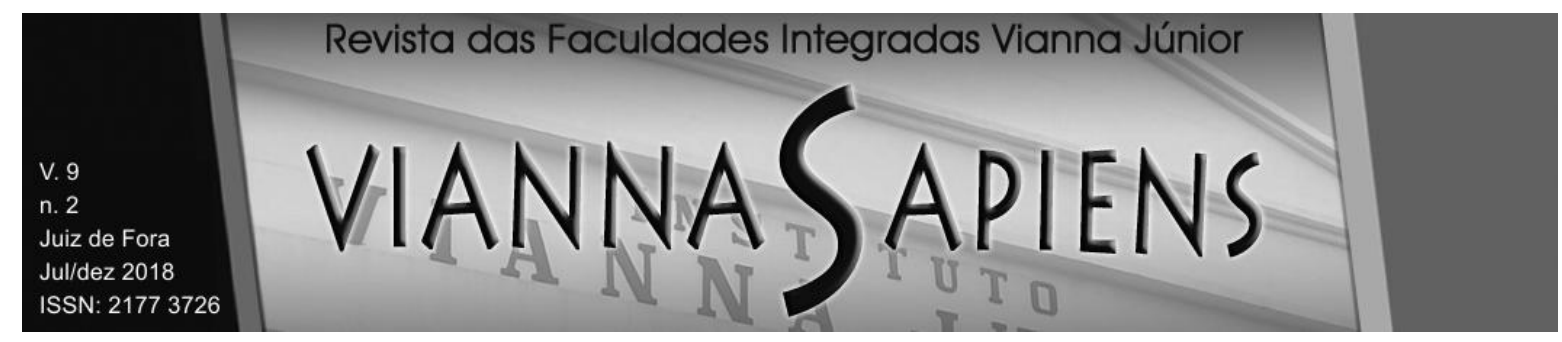

\section{INTRODUÇÃO}

Pretende-se tecer, com esse artigo, considerações e reflexões partindo de diretrizes traçadas pela Constituição Federal de 1988 sobre o princípio da dignidade da pessoa humana, um vetor máximo interpretativo de nossa hermenêutica constitucional e a constitucionalidade, ou não, do regime disciplinar diferenciado observado no processo penal, contudo, com um viés contemporâneo, democrático e garantidor.

Diante das mudanças ocorridas na sociedade, observa-se a crescente aglomeração dos presos nos cárceres brasileiros, fato este incontroverso. Com o presente estudo, analisar-se-á as mudanças sucedidas no sistema prisional com a introdução da Lei 7210/84 - Lei de Execução Penal -, que inseriu o Regime Disciplinar Diferenciado no ordenamento jurídico brasileiro. Igualmente, a Lei 10792/2003, que alterou artigos da Lei de Execução Penal e, com isso, trouxe uma grande discussão a respeito do tema, uma vez que esse regime disciplinar se mostrou um tanto rigoroso e cruel e, talvez, além dos limites da pessoa humana.

Busca-se alcançar o efetivo papel da prisão, de maneira a garantir a ressocialização do preso, bem como sua reinserção na sociedade de forma digna, mas, sobretudo, garantir, durante todo o tempo que se encontra em privação da sua liberdade, todos os direitos que ainda Ihe são assegurados pela Carta Magna.

Bem assim, para efetivar esse estudo foi realizada uma pesquisa bibliográfica, documental e de campo, apoiando-se nas doutrinas e nas jurisprudências de nossos tribunais, que permitiram delinear uma nova abordagem sobre o tema, chegando a conclusões que possam servir de embasamento para pesquisas futuras.

Nesse viés, o primeiro item tem como base o princípio da dignidade da pessoa humana, que é aquele que garante um mínimo de respeito ao ser humano simplesmente pelo fato de ser ele homem. Em outras palavras, todas as pessoas são munidas por natureza de igual dignidade. Ressalta-se que o respeito à pessoa 


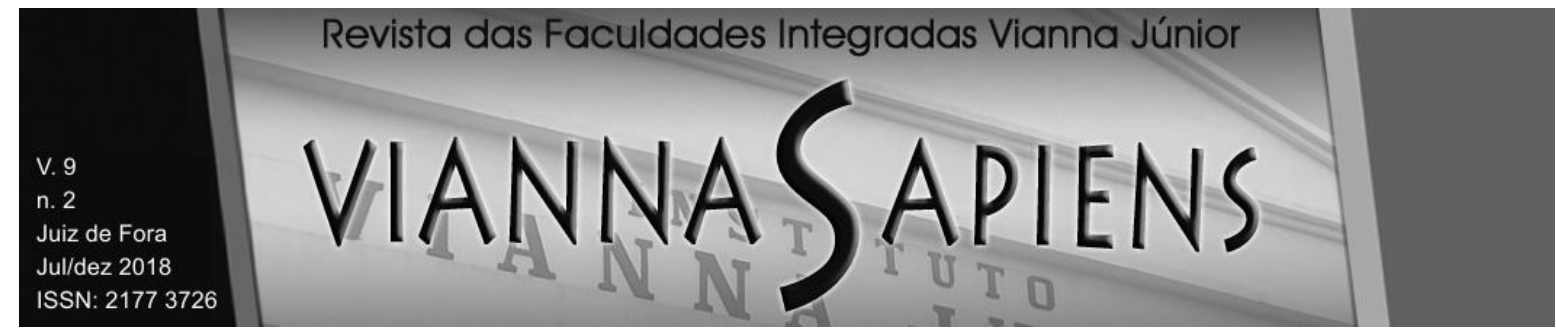

humana deve estar presente independente de grupo ou classe social, raça, etnia, a que aquele faça parte.

Em uma segunda abordagem, o item de número dois, visa expor um paralelo entre os direitos e garantias fundamentais inerentes a todo ser humano, quais sejam a proibição a tortura e ao tratamento cruel, desumano ou degradante, o direito a assistência religiosa aos presos, a proibição às penas cruéis, o respeito à integridade física e moral dos presos, bem como o amparo da família e do advogado; e o regime disciplinar diferenciado, verificando se este realmente resguarda estes direitos e garantias, igualmente se está em conformidade com os princípios constitucionais que analisaremos.

O terceiro item tem como objetivo traçar a trajetória do princípio da dignidade da pessoa humana através da história da humanidade e, por fim, as conclusões gerais encontram-se na parte final deste estudo.

\section{O PRINCÍPIO DA DIGNIDADE DA PESSOA HUMANA}

A conquista dos direitos individuais, coletivos e sociais se mostra intimamente interligada ao contexto histórico e social em que estes advieram.

A Constituição Federal do Brasil de 1988 foi elaborada num cenário de pósditadura e de abertura política, aliados ao profundo sentimento de indispensabilidade de solidariedade entre os povos. Assim, constata-se a expressão de uma nova era das garantias individuais, resultado de lutas e abusos no árduo caminho do reconhecimento dessas liberdades até se alcançar a promulgação desse texto.

Outra constituição a ser citada é a Constituição da Alemanha Ocidental do pós-guerra ${ }^{3}$, que possui, segundo tradução de Nelson Nery Junior, em seu artigo

3 A elaboração da Carta Magna alemã foi autorizada pelos três aliados ocidentais nos
chamados Documentos de Frankfurt, em julho de 1948. Esta Assembleia Constituinte, batizada de 


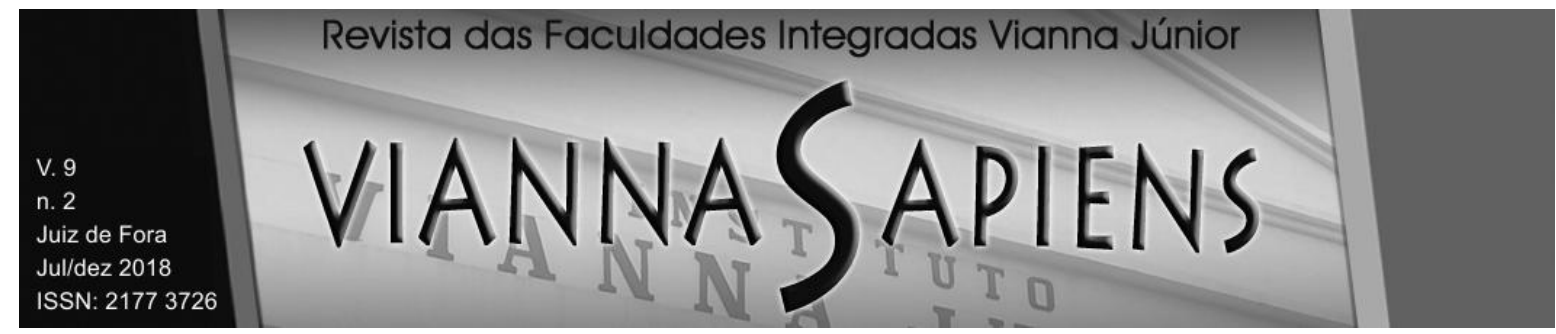

inicial feito por Rizzatto Nunes (2009), a seguinte afirmação: "A dignidade humana é intangível. Respeitá-la e protegê-la é obrigação de todo o poder público". A própria Declaração Universal dos Direitos Humanos de 1948, em seu art.1ํㅜ, informa: "todas as pessoas nascem livres e iguais em dignidade e direitos".

Dentre os fundamentos do Estado brasileiro, a dignidade da pessoa humana possui um papel de destaque. Segundo Marcelo Novelino (2015), é núcleo axiológico do constitucionalismo hodierno, o qual constitui valor constitucional supremo e, enquanto tal, deve servir não apenas como razão para a decisão de casos concretos, mas, fundamentalmente, como diretriz para a elaboração, interpretação e aplicação das normas que compõem a ordem jurídica em geral e o sistema de direitos fundamentais, em particular.

Bem assim, como consequência da consagração da dignidade humana no texto constitucional, impõem-se o reconhecimento de que a pessoa não é simplesmente um reflexo da ordem jurídica, mas, ao contrário, constitui o seu objetivo supremo, sendo que na relação entre o indivíduo e o Estado deve haver sempre uma "presunção a favor do ser humano e de sua personalidade". O indivíduo precisa servir de "limite e fundamento do domínio político da República", pois o Estado existe para o homem e não o homem para o Estado (CANOTILHO, 1993).

A positivação constitucional impõe que a dignidade, apesar de ser originariamente um valor moral, seja reconhecida também como um valor tipicamente jurídico, revestido de normatividade: sua consagração como fundamento do Estado brasileiro não significa uma atribuição de dignidade às pessoas, mas sim a imposição aos poderes públicos do dever de respeito e proteção da dignidade dos indivíduos, assim como a promoção dos meios necessários a uma vida digna.

No seu preâmbulo, a CF/88 faz menção ao Estado Democrático de Direito como forma de garantir os exercícios dos direitos sociais e individuais. Em

Conselho Parlamentar, foi formada por 65 representantes de assembleias estaduais da Alemanha Ocidental e cinco observadores enviados por Berlim.

${ }^{4}$ Artigo 1. Todas os seres humanos nascem livres e iguais em dignidade e direitos. São dotados de razão e consciência e devem agir em relação uns aos outros com espírito de fraternidade. 


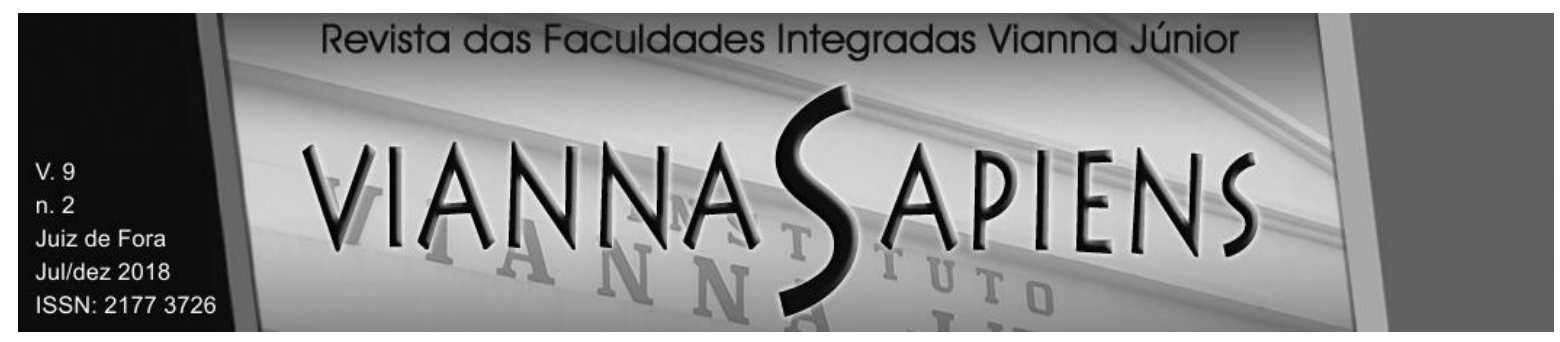

sequencia, no artigo 1을 incisos I e II e no artigo 170, caput, verifica-se a incumbência da ordem econômica em assegurar a todos uma existência digna. No artigo 226, $§ 7^{\circ}$, foi dado ênfase à família, como forma de garantir a dignidade da pessoa humana. Em seu artigo $3^{\circ}$, inciso III e o artigo 23, inciso X, apresentado como "dos objetivos fundamentais", está a "exterminação da pobreza e das desigualdades sociais". A Carta Magna traz, em seu artigo 6o, o mínimo que cada indivíduo necessita: educação, saúde, trabalho, moradia, lazer, segurança, previdência social, a proteção à maternidade e à infância e a assistência aos desamparados. Também assegura no art. $5^{\circ}$, inciso XLIX, o respeito à integridade física e moral dos presos. Já no inciso $L$, há instrução no sentido de que "às presidiárias serão asseguradas as condições para que possam permanecer com seus filhos durante o período de amamentação". Destarte, todos os direitos sociais supracitados estão intimamente ligados à dignidade da pessoa humana.

Entretanto, apesar de todas as previsões legais demonstradas, na prática, o Estado não tem conseguido garantir esse "mínimo constitucional", o que, aliado à falta de informação da sociedade quanto aos seus direitos ou de como exercê-los, tem, como resultado, a falta de aplicabilidade da vontade do legislador originário.

Sendo assim, não há como falar em desconsideração da dignidade da pessoa humana em nenhuma forma de interpretação, aplicação e/ou criação de normas jurídicas, pois concerne um supraprincípio constitucional. Nos termos de Beatrice Maurer (2005), ipsis litteris:

A pessoa não tem mais ou menos dignidade em relação à outra pessoa. Não se trata, destarte, de uma questão de valor, hierarquia, de uma dignidade maior ou menor. E por esse motivo que a dignidade do homem é um absoluto. Ela é total e indestrutível. Ela é aquilo que chamamos inamissível, não pode ser perdida.

A partir de tais considerações, é possível afirmar que a dignidade da pessoa humana, enquanto fundamento da República Federativa do Brasil, possui uma tripla dimensão normativa, senão vejamos: 


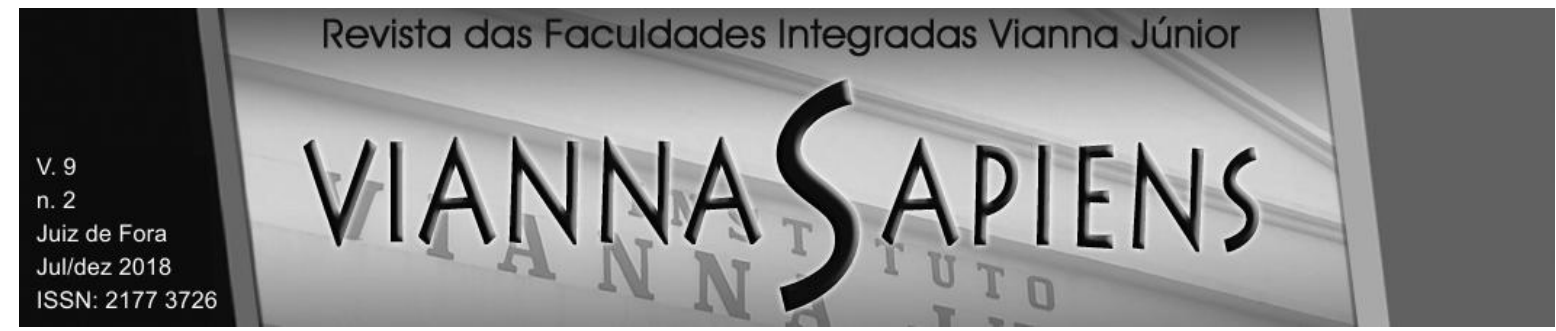

i) Metanorma - que atua como diretriz a ser observada na criação e interpretação de outras normas;

ii) Princípio - que impõe aos Poderes Públicos o dever de proteção da dignidade e de promoção de valores, bens e utilidades indispensáveis a uma vida digna;

iii) Regra - a qual determina o dever de respeito à dignidade, seja pelo Estado, seja por terceiros, no sentido de impedir o tratamento de qualquer pessoa como um objeto, quando este tratamento for expressão do desprezo pelo ser humano.

Dessa forma, há que se observar as nuances da aplicação do referido princípio na dogmática constitucional brasileira, no tocante à sua consagração como Estado Democrático de Direito.

\subsection{A DIGNIDADE DA PESSOA HUMANA NO ORDENAMENTO JURÍDICO BRASILEIRO}

Identifica-se que nosso ordenamento dispõe, nas palavras de Ingo Sarlet (2006) de uma Constituição de feição, in verbis:

Marcadamente compromissário, que elevou a dignidade da pessoa humana à condição de fundamento de nosso Estado democrático de Direito. Nossa carta magna é considerada uma Constituição da pessoa humana ainda que não raras vezes este dado venha a ser virtualmente desconsiderado (2006, p.61 e 68).

Os presídios brasileiros são comumente conhecidos como verdadeiros "depósitos humanos", onde mulheres e homens são ali "largados", sem o mínimo de respeito como ser humanos que são. As condições destes cárceres podem ser comparadas a verdadeiras penas cruéis, exercidas na idade média ${ }^{5}$.

\footnotetext{
${ }^{5}$ As penas de prisão na idade média eram marcadas, essencialmente, pela crueldade com a qual os indivíduos eram tratados. Não havia qualquer observância à proporcionalidade e visavam,
} 


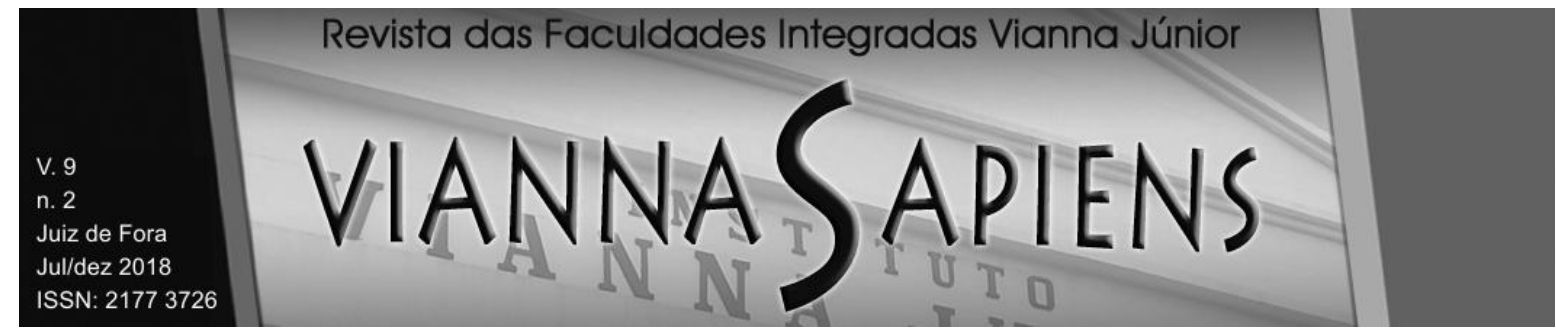

Para evitar esse tipo de situação, é crucial que, no momento em que o apenado é apresentado ao sistema prisional, haja um acompanhamento adequado para que sejam respeitados os direitos inerentes de todo e qualquer ser humano.

Dessa maneira, imperiosamente haverá uma divergência entre a dignidade que desejemos preservar e a aplicação da pena corretiva, aqui percebida como correção pela violação de uma norma penal, porquanto a pena privativa mais rigorosa, ainda que eventualmente necessária, não deve ser desproporcional, visto que a suportabilidade humana não é ilimitada. Por isso de suma importância trabalhar o princípio da dignidade da pessoa humana como limitador do poderio punitivo do Estado.

\subsection{A DIGNIDADE DA PESSOA HUMANA NO ORDENAMENTO JURÍDICO INTERNACIONAL}

De forma expressa, a dignidade da pessoa humana passou a ser reconhecida nas constituições somente após a Segunda Guerra Mundial, logo após ter sido consagrada pela Declaração Universal da ONU em 1948. Neste sentido, oportuna é a lição de Celso Lafer (1988) na obra "A Reconstrução dos Direitos Humanos" (1988, p. 19 e 20 :

A convicção, explicitamente assumida pelo totalitarismo, de que os seres humanos são supérfluos e descartáveis, representa uma contestação frontal à ideia do valor da pessoa humana enquanto 'valor-fonte' de todos os valores políticos, sociais e econômicos e, destarte, o fundamento último da legitimidade da ordem jurídica, tal como formulada pela tradição, seja no âmbito do paradigma do Direito Natural, seja no da Filosofia do Direito. O valor da pessoa humana enquanto 'valor-fonte' da ordem de vida em sociedade

exclusivamente, ao sofrimento do apenado, em visão unicamente retributiva e punitiva. Não havia, assim, a ideia de respeito à dignidade da pessoa humana, bem como o caráter ressocializador da pena. 


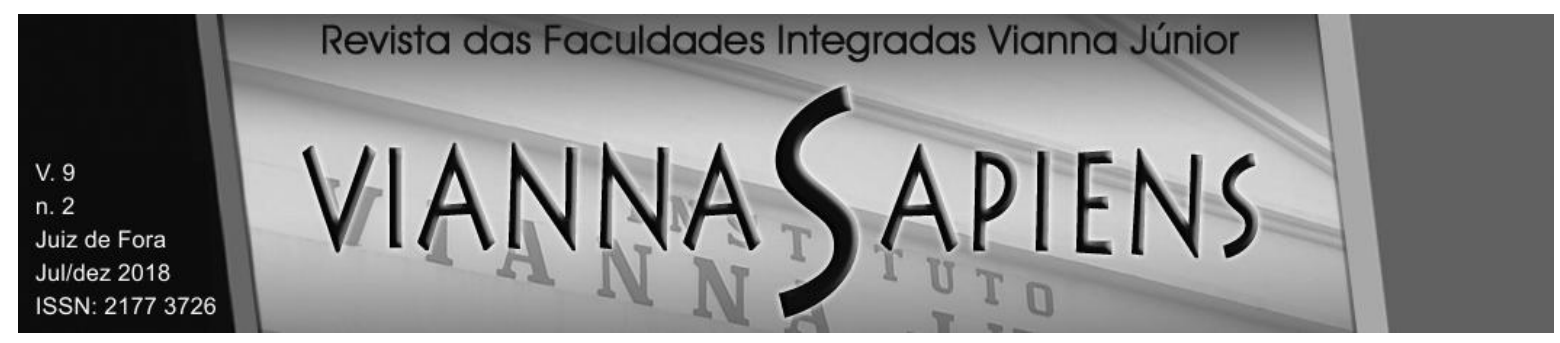

encontra a sua expressão jurídica nos direitos fundamentais do homem).

Nesse contexto, salientam-se constituições estrangeiras que também reconhecem e legitimam a dignidade da pessoa humana. São elas: a Constituição da Alemanha (artigo 1ํㅜㄹ inciso I), a Constituição da Espanha (preâmbulo e artigo. 10.1), a da Grécia (artigo 2º inciso I), a da Irlanda (preâmbulo), a de Portugal (artigo $1^{\circ}$ ), bem como a Constituição da Itália (artigo $3^{\circ}$ ).

Na América Latina, especificamente no Mercosul, somente as Constituições do Brasil (artigo 1ํㅜㄹ inciso III) e a do Paraguai (preâmbulo) equipararam o valor da dignidade ao status de norma fundamental. No tocante aos demais Estados, recomenda-se a Constituição de Cuba (artigo 8º) e a Constituição da Venezuela (preâmbulo). Na Carta Magna Peruana, também encontramos referência à dignidade da pessoa humana, onde são reconhecidos demais direitos, que derivam da dignidade da pessoa humana, da soberania popular, do Estado Social e Democrático de Direito e da Forma Republicana de Governo.

\section{A (IN) CONSTITUCIONALIDADE DO REGIME DISCIPLINAR DIFERENCIADO}

Sabe-se que o princípio da individualização da pena, consagrado no inciso XLVI do artigo $5^{\circ}$, da Constituição Federal de $1988^{6}$, impõe que as sanções penais sejam fixadas, aplicadas e executadas de modo justo e proporcional, tendo em vista aspectos objetivos (natureza e circunstancias do delito) e subjetivos (características pessoais do infrator) do crime.

Conquanto, não foi esse caminho que o legislador perseguiu ao institucionalizar o Regime Disciplinar Diferenciado, mais conhecido como RDD,

\footnotetext{
${ }^{6}$ Art. 5o, XLVI - a lei regulará a individualização da pena e adotará, entre outras, as seguintes: a) privação ou restrição da liberdade; b) perda de bens; c) multa; d) prestação social alternativa; e) suspensão ou interdição de direitos.
} 


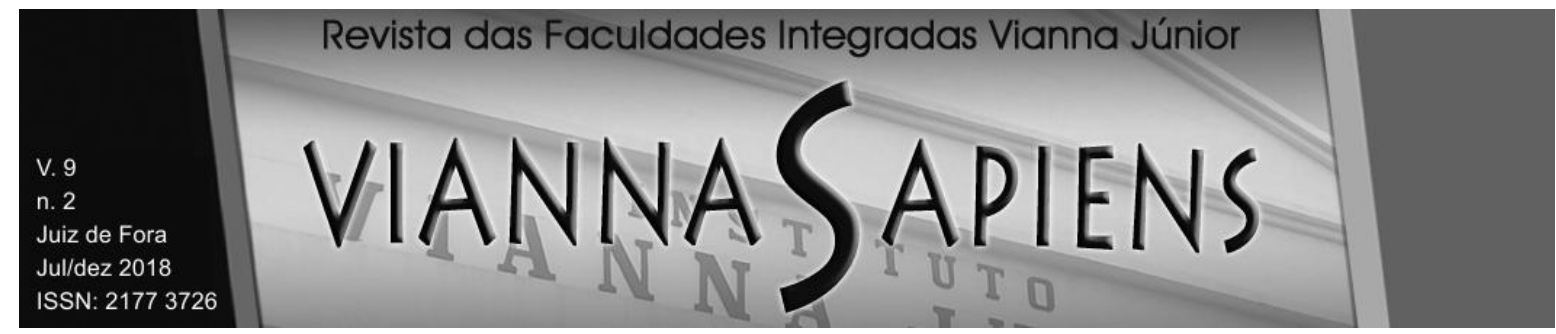

acabando por assumir uma posição diametralmente oposta aos direitos e garantias fundamentais que a própria Constituição assegura, corrompendo e destoando os princípios humanizadores de política penal e penitenciária. Princípios estes, reconhecidos em Tratados Internacionais ${ }^{7}$, os quais o Brasil ratificou.

Inequivocamente, dentre os direitos fundamentais que o legislador desrespeitou ao instituir o regime disciplinar diferenciado, o mais importante deles, porque o mais fundamental, é o princípio da dignidade da pessoa humana, base de toda atual civilização ${ }^{8}$.

Primeiramente, mister ponderar que o RDD foi implantado no Brasil com a finalidade de controlar a violência extrema que acometeu o país, além de obstaculizar a ação do crime organizado, cujos líderes continuavam emitindo ordens e praticando outros crimes de dentro da prisão.

Questiona-se, assim, se a inserção de um preso no sistema do RDD seria a melhor solução, tendo em vista o objetivo ressocializador da pena. Será que submeter indivíduos de conturbada formação moral ao confinamento extremo teria, realmente, um viés educacional e integrativo?

Pelo contrário, acredita-se que esse isolamento, estabelecido de forma mais rigorosa do que a já existente, produz nos presos, sejam eles condenados ou provisórios, efeitos vastos em sua psique que, em sua grande maioria, serão inconversíveis. Sem dúvida, há que se considerar que as condições às quais o preso é submetido, quando inserido no RDD, tendem a levá-lo à insanidade, uma vez que permanecerá um ano em total isolamento, sem permissão de contato com os demais detentos, sem acesso às informações do cotidiano e, ainda, sendo-lhe permitido, somente por duas horas, contato com a luz solar.

Versa-se, inicialmente, de um completo desrespeito ao preceito constitucional

\footnotetext{
${ }^{7}$ Art. 5으, LXXVIII, § $3^{\circ}$ - os tratados e convenções internacionais sobre direitos humanos que forem aprovados, em cada Casa do Congresso Nacional, em dois turnos, por três quintos dos votos dos respectivos membros, serão equivalentes às emendas constitucionais.

${ }^{8}$ Art. 10 - A República Federativa do Brasil, formada pela união indissolúvel dos Estados e Municípios e do Distrito Federal, constitui-se em Estado Democrático de Direito e tem como fundamentos: III. a dignidade da pessoa humana;
} 


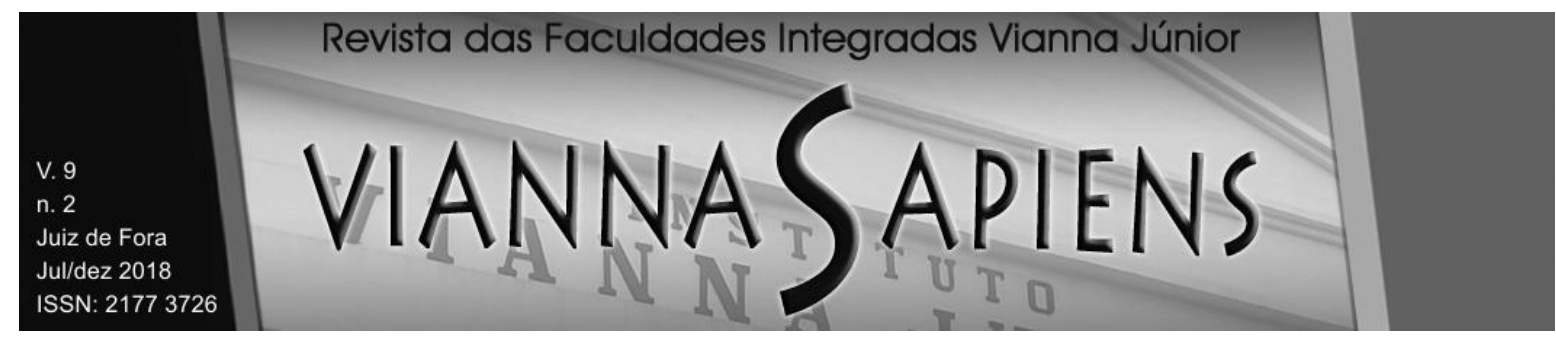

que assegura ao detento a preservação da sua integridade física e moral; segundo, contraria uma das finalidades da pena, qual seja, a recuperação do condenado. Esta, por sua vez, restará obviamente prejudicada, porque, em regime de isolamento, o preso ficará impossibilitado de trabalhar e de frequentar cursos de profissionalização. Observe-se o que expõe jurisprudência do STF, nesse sentido o Recurso Ordinário em Habeas Corpus, RHC 124775/RO, publicada em 18 de dezembro de 2014, in verbis:

Recurso ordinário constitucional. Habeas corpus. Execução Penal.Remição. Inexistência de meios, no estabelecimento prisional, para o desempenho de atividades laborais ou pedagógicas. Pretendidocômputo fictício de potenciais dias de trabalho ou estudo.Inadmissibilidade. Necessidade do efetivo exercício dessas atividades. Preso, ademais, sob regime disciplinar diferenciado (RDD). Inexistência de previsão legal para que deixe a cela para executar trabalho interno. Recurso não provido. 1 . O direito à remição pressupõe o efetivo exercício de atividades laborais ou estudantis por parte do preso, o qual deve comprovar, de modo inequívoco, seu real envolvimento no processo ressocializador, razão por que não existe a denominada remição ficta ou virtual. 2. Por falta de previsão legal, não há direito subjetivo ao crédito de potenciais dias de trabalho ou estudo em razão da inexistência de meios para o desempenho de atividades laborativas ou pedagógicas no estabelecimento prisional. 3. 0 Regime Disciplinar Diferenciado impõe ao preso tratamento penitenciário peculiar, mais severo e distinto daquele reservado aos demais detentos, estabelecendo que o preso somente poderá sair da cela individual, diariamente, por duas horas, para banho de sol. 4. Não há previsão, na Lei de Execucão Penal, para que o preso, no regime disciplinar diferenciado, deixe a cela para executar trabalho interno, o que também se erige em óbice ao pretendido reconhecimento do direito à remicão ficta.

(STF - RHC: 124775 RO, Relator: Min. DIAS TOFFOLI, Data de Julgamento: 11/11/2014, Primeira Turma, Data de Publicação: DJE250 DIVULG 18-12-2017 PUBLIC 19-12-2014) (grifo nosso)

Um dos questionamentos mais clássicos da filosofia e da teoria do direito penal é a justificativa do uso de violência, da imposição de sanções pelo poder público, que definem os princípios reitores dos sistemas jurídicos penais e 


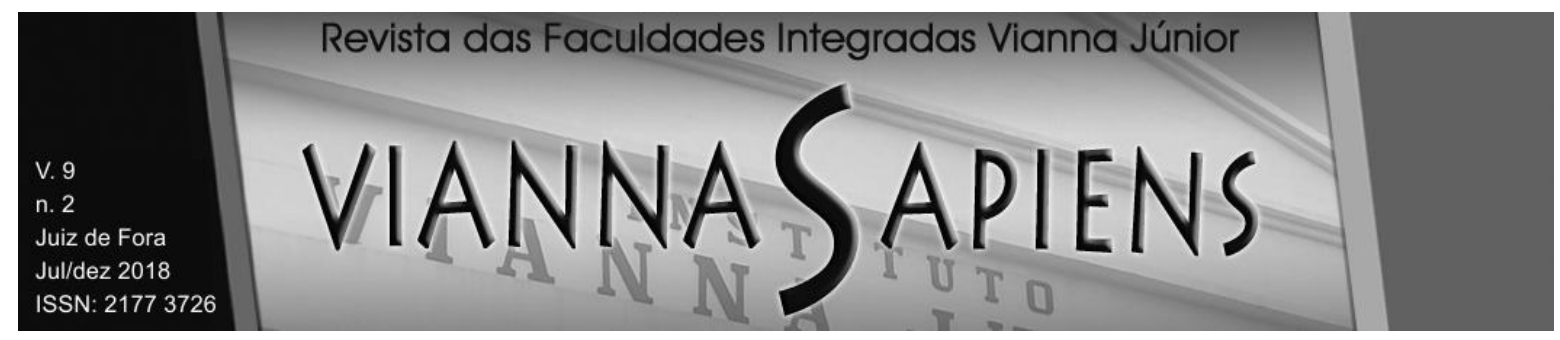

processuais. Como vaticinou Ferrajoli (2002):

O problema da legitimidade política e moral do direito penal como técnica de controle social mediante contrições da liberdade dos cidadãos é, em boa parte, o próprio problema da legitimidade do Estado como monopólio organizado pela força.

Pode-se perceber que a própria estrutura do sistema prisional viola e descumpre o princípio da dignidade da pessoa humana, visto que mantém encarcerados indivíduos reincidentes junto com primários. Aqueles que cometeram delitos graves juntamente com sujeitos que incorreram em infrações de menor potencial ofensivo. Presos de forma cautelar com condenados definitivos. Ou seja, faz com que as prisões sejam conhecidas como verdadeiras universidades do crime.

Muito mais do que um rígido controle disciplinar, a implementação do RDD nos presídios brasileiros representa, segundo Salo de Carvalho (2004), o sentimento do Poder Público com práticas arbitrárias, senão vejamos:

A Lei 10.792/03, ao incorporar o RDD na (des)ordem jurídica nacional e alterar a LEP, vinculando o ingresso do preso no regime disciplinar diferenciado quando apresentar alto risco a ordem e a segurança do estabelecimento penal ou da sociedade (art. $52, \S 1^{\circ} \mathrm{da}$ LEP) ou quando recaiam fundadas suspeitas de envolvimento ou participação, a qualquer título, em organizações criminosas, quadrilha ou bando (art. 52, $2^{\circ}$ LEP), manifesta o sentimento dos Poderes Públicos com práticas arbitrárias, regularmente toleradas nas penitenciárias nacionais.

Isto porque a pena de prisão não ressocializa, não reeduca, tampouco reinsere. Pelo contrário, somente se efetivam a reincidência e a rejeição social. Como afirma o professor Rogério Sanches Cunha (2017):

Certamente tal regime foi sancionado para satisfazer a opinião pública, que muito ganha destaque nos dias de hoje. É absolutamente necessário, findar de uma vez por todas com a mania nacional de legislar de acordo com o interesse político e para as luzes da mídia, em detrimento do interesse social. Não é 


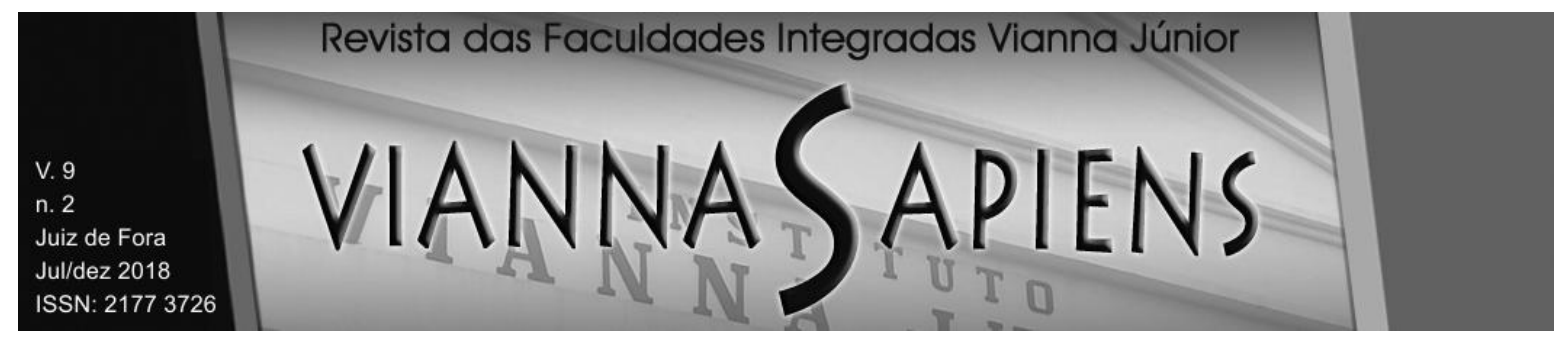

aumentando penas, castigando o detento e acrescendo 0 rol dos crimes hediondos que vamos resolver a questão da criminalidade. A certeza da punição, esta sim, daria um forte incremento na tarefa de conter o ilícito penal.

Novamente dispõe de uma solução absolutamente ineficiente para combater a criminalidade, cujas raízes todos temos conhecimento. Está na desigualdade social que ainda assombra o país. Beccaria (1983) já dizia, no século XVIII, em sua clássica obra Dos Delitos e das Penas, que entre as penalidades e o modo de aplicá-las proporcionalmente aos crimes, é necessário escolher os meios mais eficientes e mais perdurável e, igualmente, menos cruel no organismo do culpado.

Consequentemente, de nada adianta querer que somente o direito penal traga a solução para todas as atrocidades vistas atualmente. Isso porque seria além de inviável, incoerente idealizar normas penais mais rigorosas, como acontece com a indeterminação do período de isolamento dos apenados em regime disciplinar diferenciado. Mostra-se, de forma cada vez mais notória, que o Estado é ineficiente para impedir ou reduzir a multiplicação dos delitos (violentos ou não), uma vez que falta, em demasia, segurança para a população brasileira. Por conseguinte, a lei está perdendo o poder da confiança do povo, de modo que, enquanto há um pequeno volume de métodos para enfrentar e proteger a população contra esses agentes, há um aumento considerável dos crimes.

Cumpre destacar, todavia, que o sistema penitenciário brasileiro não está falido como frequentemente se diz. Falida está a pena de prisão nos moldes como é aplicada já que, há muito tempo, não vem cumprindo com seu papel, ou seja, somente deve ser aplicada para aqueles criminosos considerados de alta periculosidade, que não possam conviver em sociedade.

A pena alternativa carrega um papel preponderante para a diminuição da aplicação da pena de prisão, uma vez que, na grande maioria dos casos, previne, reprime e recupera o condenado. 


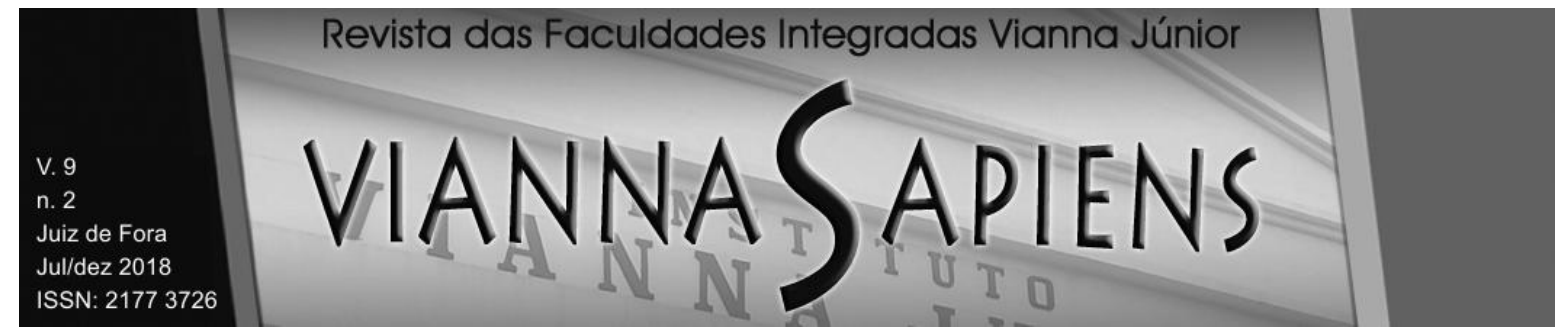

Corrobora-se que a justiça restaurativa ${ }^{9}$, como inovação e nova forma de aplicação da pena, pode ser uma solução viável, tendo em vista que o agressor e a vítima (e, às vezes, até a comunidade) participam de forma ativa no processo da superação das consequências do crime, no entendimento e no diálogo, na reparação do dano e na reintegração do infrator à sociedade, sem os sentimentos negativos da pena. Essa nova proposta já é realidade na Nova Zelândia e está sendo implementada no Brasil como forma de resolução de conflitos, por meio da mediação.

\section{APLICAÇÃO DO PRINCÍPIO DA DIGNIDADE NA HISTÓRIA}

O que seria então dignidade humana? O conceito de dignidade humana não é algo contemporâneo. É tema corriqueiro em debates e pesquisas de largo período. Em sentido filosófico e político, na antiguidade, a dignidade humana estava atrelada à posição social que ocupava o indivíduo, inclusive considerando o seu grau de reconhecimento por parte da comunidade onde estava integrado. Portanto, os primeiros passos de defesa da dignidade e dos direitos do ser humano encontramse expressos no Código de Hamurabi, da Babilônia e no Código de Manu, na Índia. Desta forma, entende-se que nesse momento histórico era possível a classificação do indivíduo como sendo mais ou menos digno, perante os outros, de acordo com seu status social.

\footnotetext{
${ }^{9}$ Em linhas gerais poderíamos dizer que se trata de um processo colaborativo voltado para resolução de um conflito caracterizado como crime, que envolve a participação maior do infrator e da vítima. Surgiu no exterior, na cultura anglo-saxã. As primeiras experiências vieram do Canadá e da Nova Zelândia e ganharam relevância em várias partes do mundo. Aqui no Brasil ainda estamos em caráter experimental, mas já está em prática há dez anos. Na prática existem algumas metodologias voltadas para esse processo. A mediação vítima-ofensor consiste basicamente em colocá-los em um mesmo ambiente guardado de segurança jurídica e física, com o objetivo de que se busque ali acordo que implique a resolução de outras dimensões do problema que não apenas a punição, como, por exemplo, a reparação de danos emocionais. Disponível em: http://www.cnj.jus.br/noticias/cnj/62272justica-restaurativa-o-que-e-e-como-funciona. Consulta em 04/05/2017.
} 


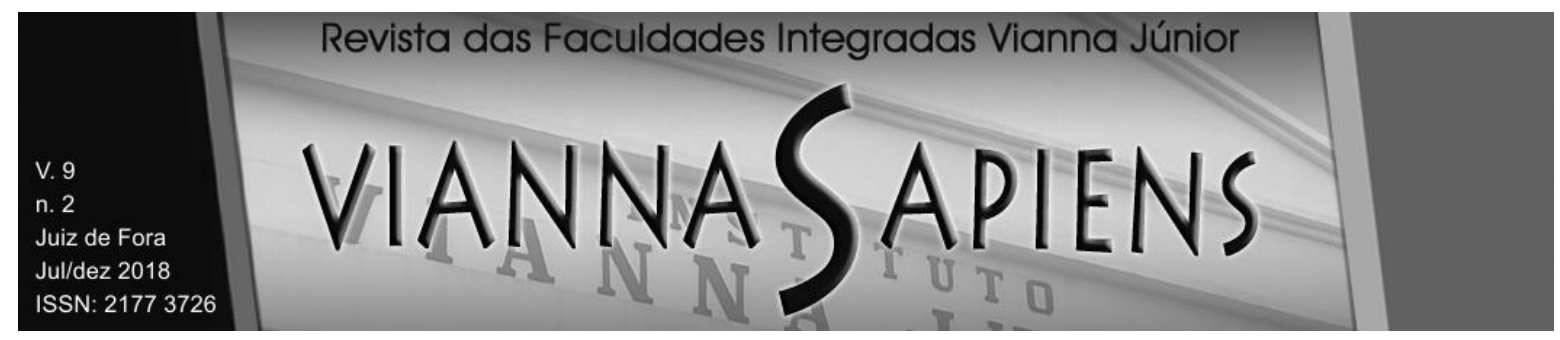

A filosofia kantiana é também responsável por uma importante contribuição sobre esse tema. Nela, por pessoa, entende-se mais que um objeto, ou seja, como valor absoluto e insuscetível de coisificação. Kant aprofunda o conceito de pessoa, a ponto de se encontrar um sujeito tratado como "um fim em si mesmo" e nunca como meio a atingir determinada finalidade. Nessa seara, Immanuel Kant $(1974)^{10}$ estabelece, como imperativo categórico, a liberdade do homem. Para ser realmente livre necessita de condições para exercer esta liberdade, que nada mais são do que os direitos fundamentais e a dignidade da pessoa humana, condições estas que devem ser proporcionadas pelo Estado.

\subsection{A DIGNIDADE DA PESSOA HUMANA COMO DIREITO ABSOLUTO}

Cuida-se aqui de saber até que ponto a dignidade da pessoa humana, visto tratar-se de um princípio fundamental, pode ser tido como absoluto, ou seja, adverso a qualquer tipo de restrição. Assim é que, segundo Sarlet (2006):

Parece-nos irrefutável que, na esfera das relações sociais, nos encontramos diuturnamente diante de situações nas quais a dignidade de uma determinada pessoa (e até mesmo de grupos de indivíduos) esteja sendo objeto de violação por parte de terceiros, de tal sorte que sempre se põe o problema - teórico e prático - de saber se é possível, com o escopo de proteger a dignidade de alguém, afetar a dignidade do ofensor, que, pela sua condição humana, é

${ }^{10} \mathrm{O}$ grande desafio de Kant, que determinou o objetivo de seu trabalho, foi o de apresentar um sistema moral que pudesse escapar dos aspectos subjetivos do utilitarismo. Em sua distinção entre Imperativos Categóricos e Imperativos Hipotéticos, Kant vê a filosofia moral de sua época com profunda insatisfação, uma vez que, segundo ele, esta não seria capaz de ultrapassar o nível dos imperativos hipotéticos. A maximização do bem para os envolvidos, premissa utilitarista, é irrelevante do ponto de vista daqueles que preocupam-se com a maximização do bem, ou do resultado positivo, apenas para si mesmos, sem importar-se com as demais pessoas. Por isto, afim de persuadir a ação moral e ser base para julgamentos morais contra as outras pessoas, seria preciso ir além do nível dos imperativos hipotéticos, que são subjetivos, uma vez que dependem do fim que se almeja atingir. Era preciso buscar um sistema moral deontológico baseado no imperativo categórico e suas exigências, uma forma de sistema moral que estivesse para além da subjetividade e pudesse ser aplicado universalmente. Disponível em: Kant. Immanuel. Fundamentação da Metafísica dos Costumes e Outros Escritos. São Paulo: Martin Claret, 2006. Coleção: A Obra Prima de Cada Autor, 2006, p. 134 a 141. 


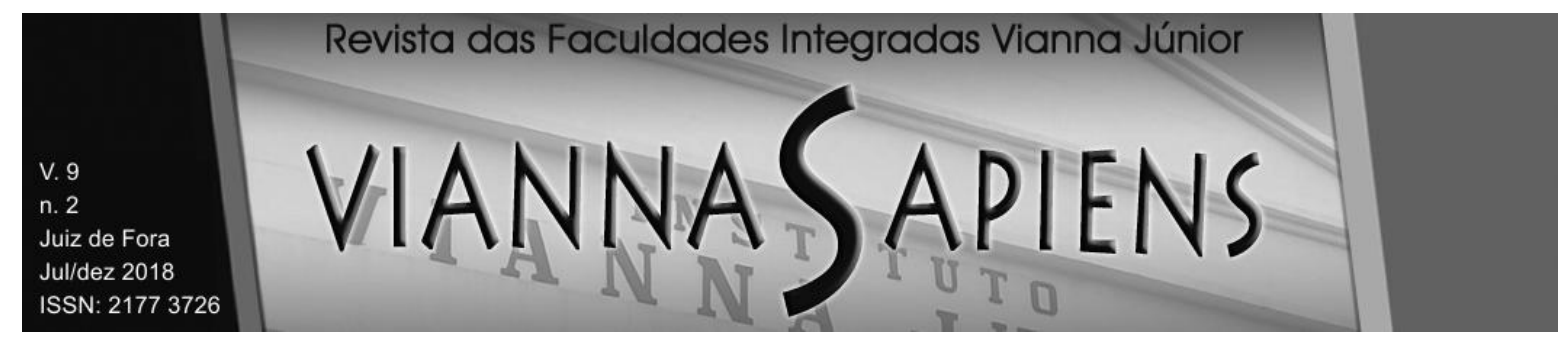

igualmente digno, mas que, ao mesmo tempo naquela circunstância, age de modo indigno e viola a dignidade dos seus semelhantes, ainda que tal comportamento não resulte - como já anunciado alhures - na perda da dignidade.

Neste mesmo contexto, ou seja, no âmbito de uma 'função protetiva' (e, portanto, defensiva) da dignidade, situa-se a noção de que a dignidade da pessoa humana constitui um dos critérios materiais para a aferição da incidência de uma proibição de retrocesso em matéria de direitos fundamentais, especialmente (mas não exclusivamente) na esfera dos direitos fundamentais sociais de cunho prestacional.

Tomando como parâmetro o princípio da dignidade da pessoa humana no sentido de limite à atividade restritiva do legislador, bem como no sentido de se relacionar dignidade e direitos fundamentais, pode se extrair do Acórdão do Tribunal de Justiça do Rio Grande do Sul, da lavra do Desembargador Adão Sérgio do Nascimento Cassiano, que o fiador, mesmo diante de disposição legal prevendo tal possibilidade, pode vir a não ter o imóvel de morada penhorado (APELAÇÃO CíVEL № 70001271766, PRIMEIRA CÂMARA ESPECIAL CÍVEL, TRIBUNAL DE JUSTIÇA DO RS, RELATOR: ADÃO SÉRGIO DO NASCIMENTO CASSIANO, JULGADO EM 20/06/2001).

\section{CONSIDERAÇÕES FINAIS}

Concluindo, tem-se que diante dos vários desdobramentos do princípio da dignidade da pessoa humana, fica evidente que não se refere a um conceito vazio ou vago, mas sim, trata-se, conforme feliz expressão da Ministra Carmem Lucia Antunes Rocha, do Supremo Tribunal Federal, do "coração do patrimônio jurídicomoral da pessoa humana". Assim, clara relação se evidencia entre a dignidade humana e o direito dos presos encarcerados no Brasil. 


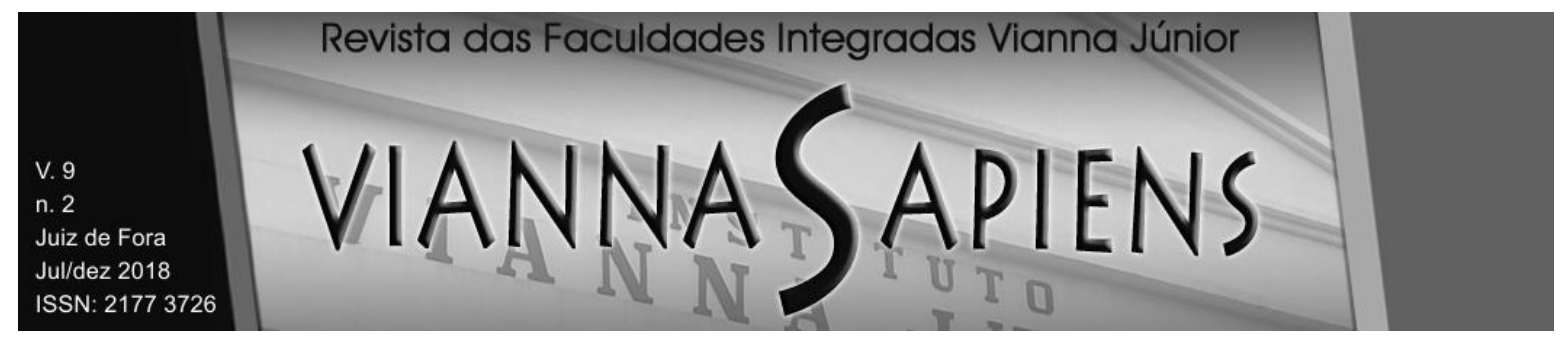

A implementação do Regime Disciplinar Diferenciado, que surgiu para aliviar a insegurança pública e disciplinar de forma mais severa os detentos, viola, expressamente, o que a Constituição Federal de 1988 assegura no tocante à dignidade física, psíquica e moral dos indivíduos. Portanto, mediante a implementação de um regime que em nada tem a ver com os preceitos traçados pelo legislador originário, questiona-se quanto a efetividade prático-social do referido tratamento. Considerando a doutrina mais festejada acerca das funções que a pena deverá ter, percebe-se que este tipo de medida é diametralmente oposta a qualquer critério que possa ser aventado de ressocialização. Foca, exclusivamente, em um tratamento punitivo. Contudo, não há se convalidar que o Estado, em prol de um bem maior, atue sobre os direitos individuais. Pior ainda, que viole, flagrantemente, tratados internacionais acerca da dignidade da pessoa humana.

Portanto, de modo a fazer com que os princípios constitucionais, cada vez mais, sejam exaustivamente almejados, é expressamente necessário se repensar o modo como a população carcerária é tratada no país. Não cabe mais, hodiernamente, aceitar que as prisões sejam escolas da criminalidade. $O$ respeito aos princípios fundamentais é pilar de sustentação do estado democrático de direito no qual se funda a sociedade brasileira. Desrespeita-lo é, pouco a pouco, ruir com essa estrutura.

\section{REFERÊNCIAS}

BRASIL. Constituição da República Federativa do Brasil de 1998. Disponível em: http://www.planalto.gov.br/ccivil 03/constituicao/constitui\%C3\%A7ao.htm. Acesso em dez. 2015.

BRASIL. Código de Processo Penal. Disponível em: http://www.planalto.gov.br/ccivil 03/decreto-lei/del3689.htm Acesso em dez. 2015 


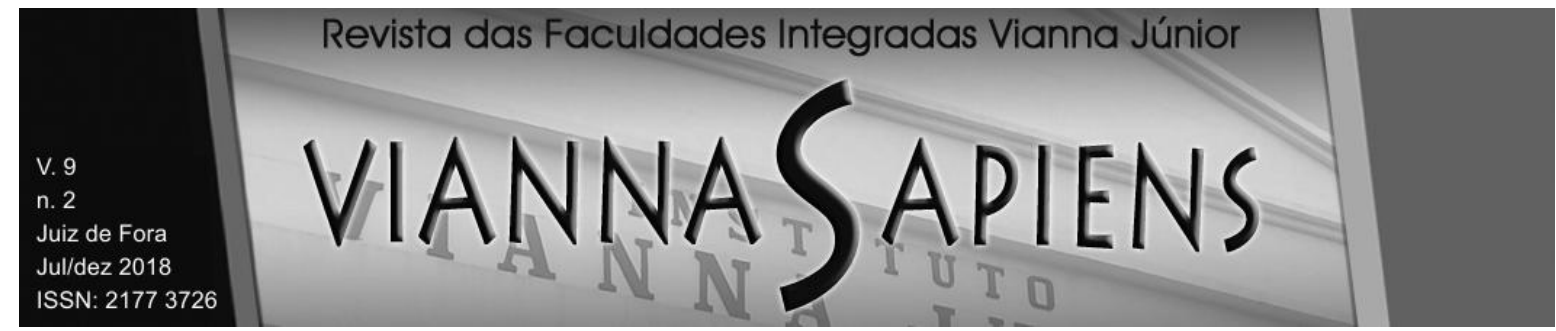

BRASIL. Lei 7.210/84 instituiu a Lei de Execução Penal, Brasília: Congresso Nacional, 1984. Acesso em dez. 2015.

BRASIL. Lei 10.792/03 modificando artigos da Lei de Execução Penal. Brasília: Congresso Nacional, 2003. Acesso em dez. 2015.

BRASIL. Resolução no $\mathbf{1 4}$, criando as regras mínimas para o tratamento de preso no Brasil. Publicada em DOU de 02/12/1994. Brasília: Conselho Nacional de Política Criminal e Penitenciária. Acesso em dez. 2015.

BECCARIA, Cesare. Dos delitos e das penas. São Paulo: Hermus, 1983.

CANOTILHO, José Joaquim Gomes. Direito Constitucional. Imprenta: Coimbra, Almedina, 1993.

CUNHA, Rogério Sanches; PINTO, Ronaldo Batista. Código de Processo Penal e Lei de Execução Penal Comentados. Salvador: Juspodivm, 2017.

CARVALHO, Salo de. Tântalo no Divã: novas críticas às reformas no sistema punitivo brasileiro. Revista do IBCCRIM, n. 50 São Paulo: Revista dos Tribunais, 2004.p. 91-118, set/out.

CONSELHO NACIONAL DE POLÍTICA CRIMINAL PENITENCIÁRIA. Disponível em: <http://www.mj.gov.br/cnpcp/>. Acesso em: 13 mar. 2006

Declaração Universal dos Direitos Humanos. Disponível em: http://portal.mj.gov.br/sedh/ct/legis intern/ddh bib inter universal.htm. Acesso em dez. 2015.

DEPARTAMENTO PENITENCIÁRIO NACIONAL. Disponível em: http://www.mj.gov.br/depen. Acesso em dez. 2015. 


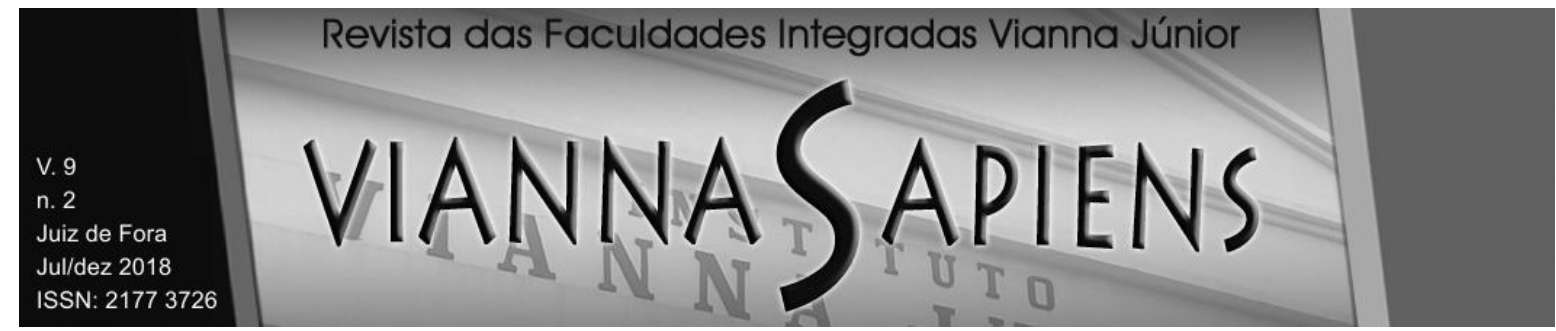

FERRAJOLI, Luigi. Direito e razão: teoria do garantismo penal. São Paulo: Revista dos Tribunais, 2002.

FOUCAULT, Michel. Vigiar e Punir. 30. ed. Petrópolis: Vozes, 2005

INFOPEN. Levantamento Nacional de Informações Penitenciárias. Disponível em: https://www.infopen.mg.gov.br/. Acesso em dez. 2015.

KANT, Immanuel. Fundamentação da metafísica dos costumes e outros escritos. São Paulo: Martin Claret, 2006. Coleção: A Obra Prima de Cada Autor, 2006, p. 134 a 141.

LAFER, Celso; ARENDR, Hannah. A reconstrução dos direitos humanos. São Paulo: Companhia das Letras, 1988

MAURER, Béatrice. Notas sobre o respeito da dignidade da pessoa humana... In: SARLET, Ingo Wolfgang (Org.) Dimensões da Dignidade. Ensaios de Filosofia do Direito e Direito Constitucional. Porto Alegre: Livraria do Advogado, 2005. p. 61-88.

MORAES, Alexandre. Direito Constitucional. 21.ed. São Paulo: Atlas.2007.

MERCOSUL. Disponível em http://www.mercosul.gov.br/saiba-mais-sobre-omercosul. Acesso em dezembro de 2017.

NOVELINO, Marcelo. Curso de direito constitucional. 10. ed. rev., Ed. Juspodivm, 2015.

NUCCI, Guilherme de Souza. Manual de processo penal e execução penal. São Paulo: Editora Revista dos Tribunais, 2010.

RIZZATO NUNES, Luiz Antonio. O Princípio Constitucional da Dignidade da Pessoa Humana: doutrina e jurisprudência. São Paulo: Saraiva, 2009. 


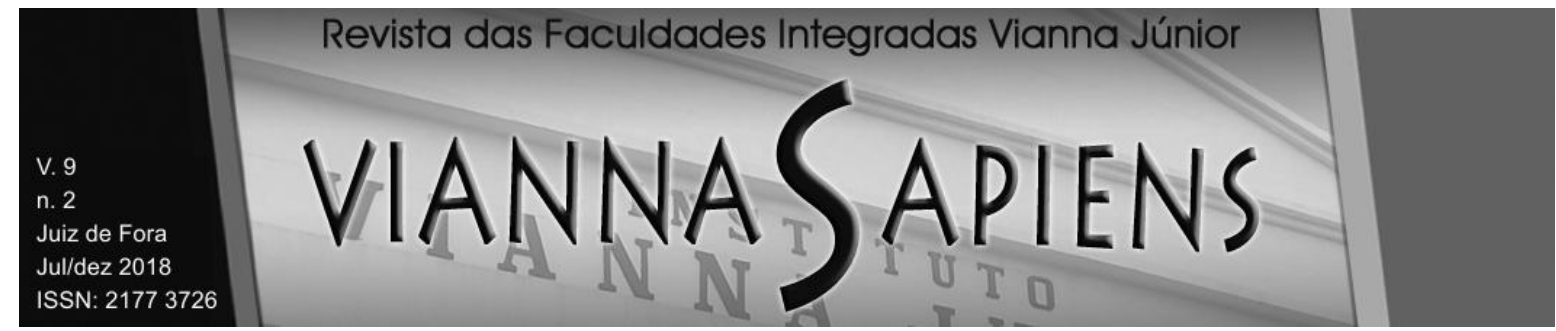

SARLET, Ingo Wolgang. Dignidade da Pessoa Humana e Direitos Fundamentais na Constituição Federal de 1988. 4 ed. Ver. Ampl. Porto Alegre: Livro do Advogado, 2006.

\section{LISTA DE ABREVIATURAS E SIGLAS}

LEP - Lei de Execução Penal

CF/88 - Constituição Federal

ONU - Organização das Nações Unidas

CP - Código Penal

CPP - Código Processual Penal

RDD - Regime Disciplinar Diferenciado

Lei 7210/84 - Lei de Execução Penal

Lei 10792/2003 - Lei que alterou artigos da LEP

\section{ANEXO}

Tabelas e dados estatísticos do INFOPEN:

As informações a seguir foram lançadas eletronicamente pelas unidades da federação. Eventuais divergências numéricas constatadas quando da comparação de indicadores entre os anos apresentados deverão ser interpretadas levando-se em conta diversos fatores, tais como: criação de novos estabelecimentos, atrasos na sistemática de levantamento dos quantitativos dos indicadores e inconsistência em lançamentos anteriores: 


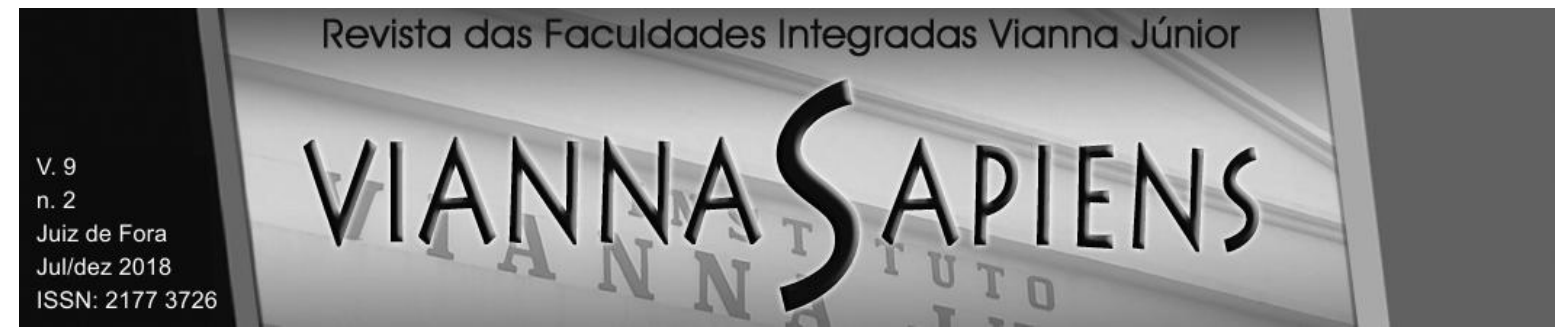

DEZEMBRO 2009 - Minas Gerais

Regime Fechado Regime Semi-Aberto Regime Aberto Homens: 11.585 Homens: 3.796 Homens: 505 Mulheres: 525 Mulheres: 172 Mulheres: 21 Total: 12.110 Total: 3.968 Total: 526

Provisório Medida de Segurança Total Estabelecimentos: 98 Homens: 16.985 Homens: 0 Mulheres: 1.532 Mulheres: 0 Total: 18.517 Total: 0

População do Sistema Penitenciário: 35.121 Vagas do Sistema Penitenciário: 23.199 Secretaria de Segurança Pública: 11.326 Pop. Prisional do Estado Masculina: 43.496 Feminina: 2.951 Total: 46.447
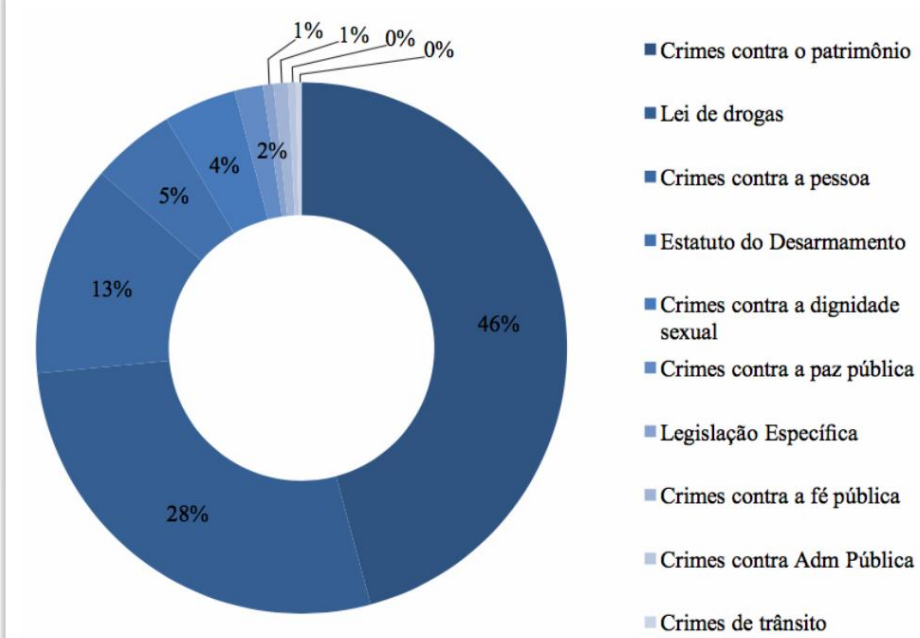


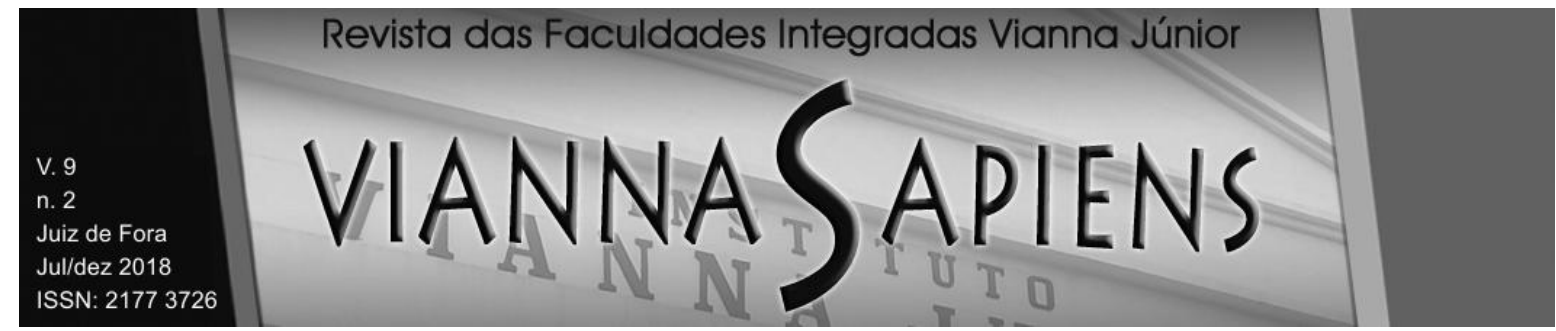

Presidios superlotados

Veja o deficit de vagas em prisões por estado

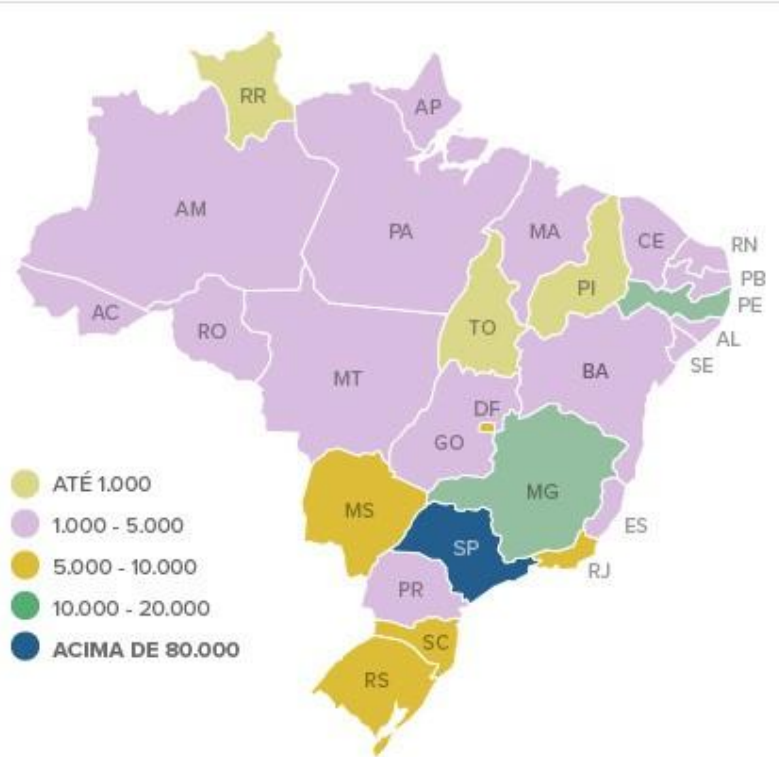

\author{
$\mathbf{5 6 3 , 7}$ mil é o número de \\ todos os estados \\ 363,5 mil é a capacidade \\ das prisões
}

DEFICIT POR ESTADO

\begin{tabular}{|c|c|c|c|}
\hline AC & 1.998 & PB & 3.440 \\
\hline AL & 2.580 & PR & 3.818 \\
\hline AP & 1.298 & PE & 19.467 \\
\hline AM & 4.620 & PI & 917 \\
\hline BA & 3.123 & RJ & 6.831 \\
\hline CE & 3.790 & RN & 2.500 \\
\hline DF & 5.703 & RS & 5.639 \\
\hline ES & 1.847 & RO & 2.912 \\
\hline GO & 4.000 & RR & 480 \\
\hline MA & 1.242 & SC & 5.900 \\
\hline MT & 4.083 & SP & 83.506 \\
\hline MS & 5.860 & SE & 1.800 \\
\hline MG & 17.944 & TO & 744 \\
\hline PA & 4.161 & & \\
\hline
\end{tabular}

G1

com.br

Infográfico elaborado em 14/01/2014 e atualizado em 15/1/2014

\begin{tabular}{|c|c|c|c|}
\hline \multirow{2}{*}{ Regiões } & $\begin{array}{r}\text { Tabela 01: Estabeibecimertos que martem os presç separados conforme a perioucaidade } \\
\text { separados conforme a natureza } \\
\text { do delito cometido } \\
\text { (periculosidade)? }\end{array}$ & \multirow{2}{*}{ Total de respondentes } \\
\cline { 2 - 3 } & Sim & Não & \\
\hline Centro-oeste & 92 & 194 & 286 \\
\hline Nordeste & 80 & 219 & 299 \\
\hline Norte & 40 & 128 & 168 \\
\hline Sudeste & 175 & 394 & 569 \\
\hline Sul & 122 & 154 & 276 \\
\hline
\end{tabular}




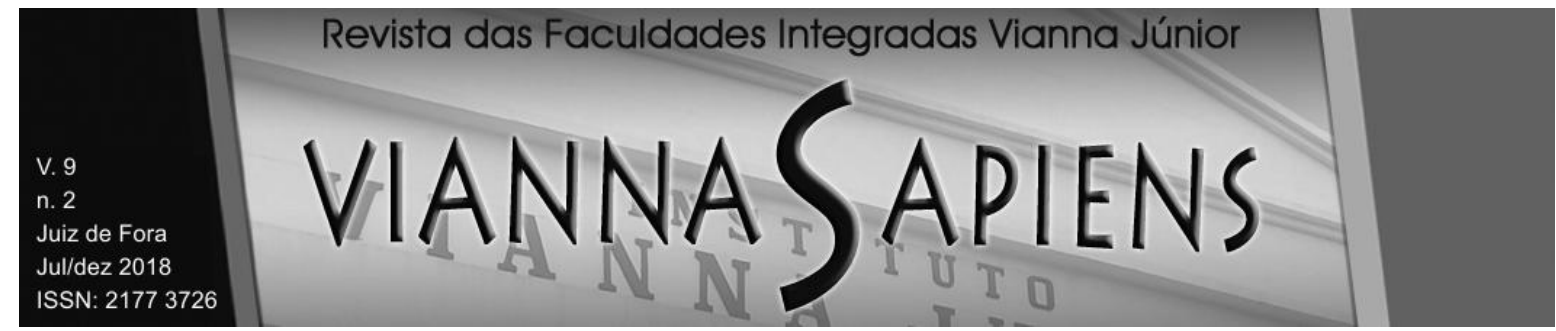

\begin{tabular}{lr}
\hline \multicolumn{2}{c}{ Brasil - 2014 } \\
\hline População prisional & 607.731 \\
Sistema Penitenciário & 579.423 \\
Secretarias de Segurança/Carceragens & 27.950 \\
de delegaciais & \\
Sistema Penitenciário Federal & 358 \\
Vagas & 376.669 \\
Déficit de vagas & 231.062 \\
Taxa de ocupação & $161 \%$ \\
Taxa de aprisionamento & 299,7 \\
\end{tabular}

\section{REFERÊNCIAS DO ANEXO}

CONSELHO NACIONAL DE POLÍTICA CRIMINAL PENITENCIÁRIA . Disponível em: <http://www.mj.gov.br/cnpcp/>. Acesso em: 08 de junho de 2016.

DEPARTAMENTO PENITENCIÁRIO NACIONAL. Disponível em http://www.mj.gov.br/depen. Acesso em dez. 2015.

DECLARAÇÃO UNIVERSAL DOS DIREITOS HUMANOS. Disponível em: http://portal.mj.gov.br/sedh/ct/legis intern/ddh bib inter universal.htm. Acesso em dez. 2015.

INFOPEN. Levantamento Nacional de Informações Penitenciárias. Disponível em: https://www.infopen.mg.gov.br/. Acesso em dez. 2015.

\section{CASOS CONCRETOS}

A primeira modalidade de regime disciplinar diferenciado ocorreu em virtude de uma rebelião ocorrida no estado de São Paulo, no ano de 2001, que envolveu vinte e cinco unidades prisionais da Secretaria da Administração Penitenciária e 


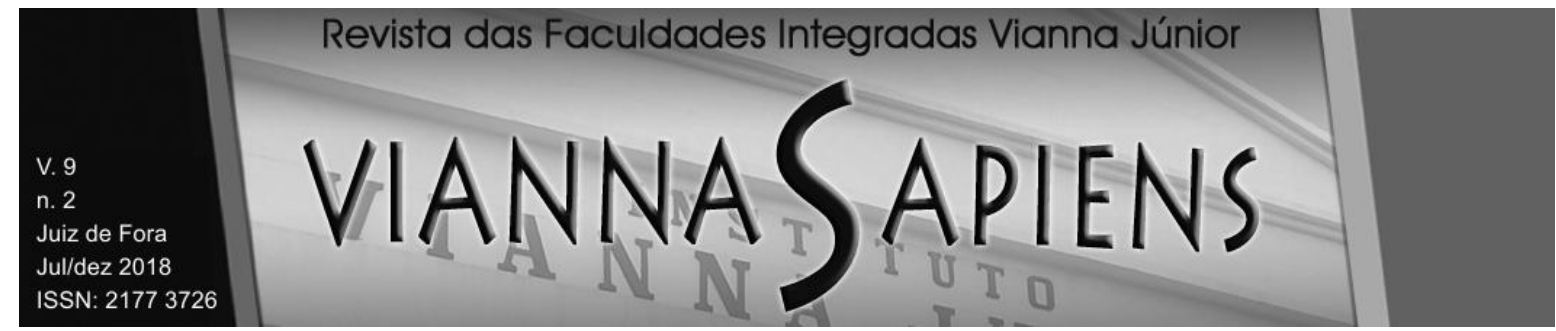

quatro cadeias públicas, sob a responsabilidade da Secretaria de Segurança Pública do Estado.

Em dezembro de 2002, ocorreu a primeira experiência do RDD no Rio de Janeiro, decorrente da rebelião no presídio de Bangu I, esta sendo comandada por Fernandinho Beira-Mar. Logo após o fim da rebelião, os líderes do movimento foram isolados para impedir o contato com os demais apenados, e o restante dos participantes foram colocados em regime disciplinar especial de segurança.

Já no ano seguinte - 2003 - a Secretaria da Administração Penitenciária do Rio de Janeiro reeditou o Regime Disciplinar Diferenciado Especial de Segurança em Bangu I, e a partir daí generalizou o modelo disciplinar para outras penitenciárias.

\section{STF e STJ:}

O Informativo 819 do Supremo Tribunal Federal trouxe um interessante julgamento envolvendo a questão da responsabilidade civil em caso de morte de presos (RE n. 841526/RS, rel. Min. Luiz Fux - REPERCUSSÃO GERAL). Segundo a decisão, nos casos de inobservância do dever específico de proteção previsto no art. $5^{\circ}$, XLIX, da CF, o Estado é responsável pela morte do preso. Ficou estabelecido que a responsabilidade civil estatal, segundo a CF/1988, em seu art. $37, \S 6^{\circ}$, subsume-se à teoria do risco administrativo, tanto para as condutas estatais comissivas quanto paras as omissivas, uma vez rejeitada a teoria do risco integral.

As decisões do STJ seguem esta mesma linha de interpretação. Ambos os Tribunais, STF e STJ, já vinham decidindo neste sentido há um bom tempo. Interessante saber que também a Corte Interamericana de Direitos Humanos sedimentou seu entendimento pela responsabilidade do Estado em caso de morte de preso.

No plano internacional, no que diz respeito aos direitos da pessoa presa, o Pacto sobre Direitos Civis e Políticos dispõe no Artigo 10: "1. Toda pessoa privada de sua liberdade deverá ser tratada com humanidade e respeito à dignidade inerente à pessoa humana". 


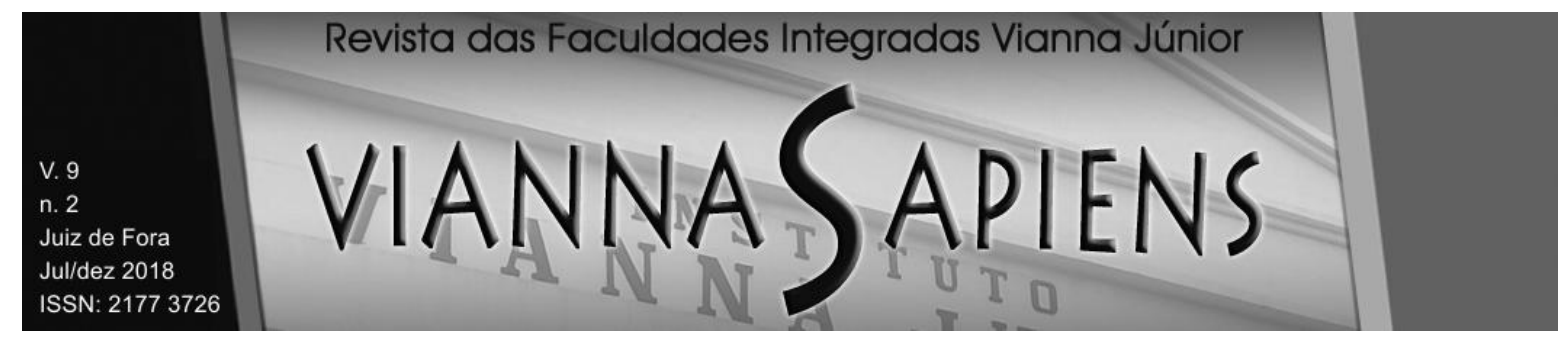

A Convenção Americana sobre Direitos Humanos (Pacto de São José da Costa Rica), de 22 de novembro de 1969, disciplina: "Artigo $5^{\circ}$ - Direito à integridade pessoal 1. Toda pessoa tem direito a que se respeite sua integridade física, psíquica e moral. 2. Ninguém deve ser submetido a torturas, nem a penas ou tratos cruéis, desumanos ou degradantes. 3. Toda pessoa privada de liberdade deve ser tratada com o respeito devido à dignidade inerente ao ser humano".

Recebido em 09/10/2018

Publicado em 21/12/2018 